\title{
Gap Analysis E-Procurement Satisfaction Service Quality Index Through Internal and External Survey Using E-Service Quality Model
}

\author{
Rahadian Agus Hamdani ${ }^{1, *}$ \\ ${ }^{1}$ Universitas Pendidikan Indonesia \\ *Corresponding author.Email: rhamdani8@gmail.com
}

\begin{abstract}
The smooth running of bank business activities is closely related to the process of procuring goods / services. Good and quality service will improve the image of the goods / services procurement department in carrying out its duties and responsibilities. Therefore, it is need the Measurement of the level of service satisfaction to determine the quality of service that has been provided. The purpose of this research is to determine the distribution of user satisfaction based on five dimensions of service quality, namely tangibles, reliability, responsiveness, assurance, empathy with two indicators, namely reality and expectations, as well as knowing the things that hinder the procurement process. The data were collected by using two types of questionnaires with a population of internal and external parties. The sampling method used was carried out by simple random sampling. Overall, all respondents expressed satisfaction with the services provided, but there were several things that need to be improved. The results of the research on the external side showed that there was a huge gap in the aspect of completeness of the electronic pre-tender process of $6.50 \%$. In the other hand, the internal side found that the biggest gap was the aspect of tender planning, namely $9.67 \%$. The dimension that needs to be a priority as a step to improve service quality so as to reduce the gap that occurs was the assurance dimension from the external side and the internal responsiveness.
\end{abstract}

Keywords: E-Procurement, Service Quality Index, Internal \& External Survey, E-Service Quality Model.

\section{INTRODUCTION}

In the process of procuring goods and services in banking institutions, a good system is needed to minimize the corruption, collusion and nepotism. In order to increase efficiency, transparency and effectiveness, the procurement of goods and services in banking institutions is carried out by using e-procurement. Not only should the implementation of e- be transparent, but also it should be carried out in all aspects of public service management.

These aspects include policy, planning, implementation, supervision or control, and performance result reports. E-procurement in banking institutions is carried out by using the Electronic Procurement System application where the implementation of e-procurement has been regulated by Presidential Decree No. 54 of 2010 concerning Procurement of Goods and Services [1].

The operational technical provisions for the procurement of goods or services electronically also refer to the regulations that have been prepared by the government [2], [3], [4]. Electronic transaction information on the implementation of the procurement of goods or services by banking institutions electronically is regulated by law [5].

Procurement of goods or services for banking institutions electronically can be done by e-tendering or e-purchasing. E-tendering is a procedure for selecting goods or services providers that is carried out openly and can be followed by all goods or service providers. It is registered in the electronic procurement system by submitting one bid within a predetermined time while Epurchasing is a procedure for purchasing goods or services through an electronic catalog system.

The scientific work refers to previous studies that used the service quality model as a method of measurement and assessment. The study was conducted using four dimensions, namely tangible, reliability, responsiveness and empathy [6]. Other research on health 
services using Servqual was used to determine whether health services were running properly or that adjustments must be made to the health demographic profile of health service users, where the quality of health services consisted of two basic dimensions, namely technical quality and clinical quality [7].

Subsequent research is about e-service, which is the most effective system in providing public services because it combines three dimensions of service, such as services, electronics, and society. The concept of eservice is defined as a service that describes information technology mediators, websites, and other mobile devices [8], [9].

The previous research has used customer satisfaction as the dependent while dimensions tangible, reliability, responsiveness, assurance, and empathy are considered independent variables. The results of the analysis using descriptive statistics, Pearson correlation, and multiple regression showed that the four variables, such as tangible, reliability, responsiveness and empathy, had a significant positive relationship with customer satisfaction. However, the assurance factor did not have a significant relationship with customer satisfaction. It implies that the companies should focus on tangible, reliability, responsiveness and empathy because they are the main indicators of customer service satisfaction.

This research measured the level of service satisfaction in order to determine the quality of services that have been provided based on five dimensions of service quality, such as tangible, reliability, responsiveness, assurance, and empathy. The purpose of this study aims to determine the distribution of user satisfaction with two variables, namely reality and expectations. The technique of data collection used came from two kinds of internal and external questionnaires which were taken randomly. Thirty external respondents consisted of auction participants, government and private companies while the internal respondents were twenty respondents, namely Commitment Making Officials, Procurement Officials, Procurement Administration Staff and E-Procurement System Admin.

\section{METHODS}

The data were collected by using internal and external surveys. Internal and external assessments involved two variables, namely unwanted and perceived expectations for goods or services procurement. Each variable used a Likert scale approach. In the measurement, there were five dimensions of satisfaction that consisted of tangible, reliability, responsiveness, assurance, and empathy.

The population of respondents for the external survey was thirty people who were randomly drawn, while the internal survey consisted of twenty commitment makers, procurement officers, administrative staff and system administrators.
Furthermore, the validity and reliability tests were carried out on the incoming answers to determine the validity and consistency of the questionnaire using the SPSS application at the data processing stage. The validity test was conducted by using the Pearson display. Invalid data would not be included in the reliability test. From the valid data, the reliability test was done with the Cronbach's alpha coefficient. The next stage was data analysis on the level of current and expected service satisfaction to determine the gap between responsiveness and expectations. The process stages are shown in picture 1

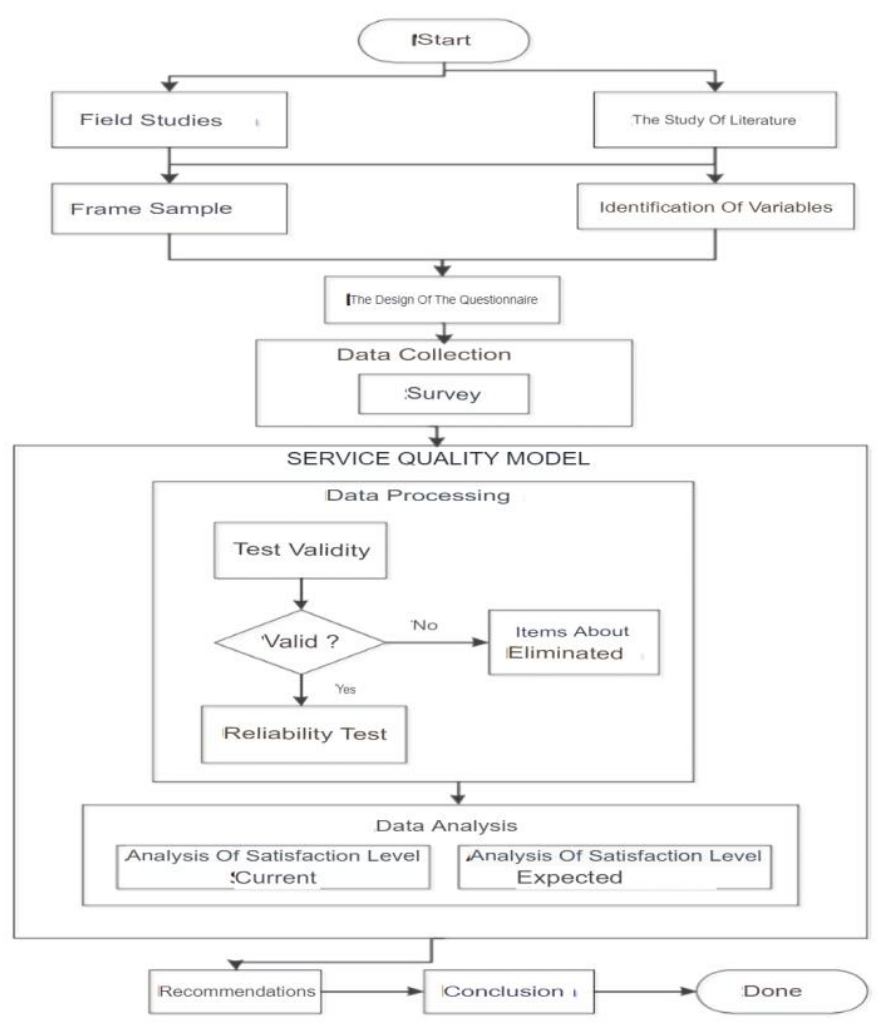

Figure 1 The diagram of research process

\section{RESULTS AND DISCUSSION}

\subsection{The findings suggest that the owner's entrepreneurial}

\subsubsection{The Result of Validity Test}

Validity testing was carried out to know the accuracy questionnaire questions to perform its measuring function, so that it was known that the question items were able to achieve the desired measurement objectives correctly or not.

In the external assessment with thirty respondents, the value of $\mathrm{n}$ was twenty-eight (30-2) and with a significance of $5 \%$, then the value of $r$ table was in 0.360 . The results of the validity test of the external assessment of the reality and expectation variables were shown in 
Table 1. From Table 1 it was known that there was one item of the reality variable that was invalid because the correlation value was in 0.198 . It means that it was smaller than the $r$ table value, 0.360, which was the user friendly electronic preview process. It was caused that the range of values in the questionnaire was too varied. There was only one item that was invalid. In addition, the question was omitted and no re-liability test was carried out. As for the expected variable, all item questions were declared valid because the correlation value was greater than the $r$ table value of 0.360 .

Table 1. Validity Test Results External Assessment with Pearson Correlation

\begin{tabular}{|c|c|c|c|c|}
\hline No & Aspect & $\begin{array}{c}\text { Reality } \\
\text { Corelation }\end{array}$ & $\begin{array}{c}\mathbf{r} \text { table } \\
\text { (sig } \\
\mathbf{5 \%}) \\
\mathrm{N}=\mathbf{3 0}\end{array}$ & $\begin{array}{c}\text { Hope } \\
\text { Corelation } \\
\text { of the } \\
\text { pretender } \\
\text { electronicic }\end{array}$ \\
\hline 1 & $\begin{array}{l}\text { Theability of the } \\
\text { employee }\end{array}$ & 0,775 & 0,360 & 0,824 \\
\hline 2 & $\begin{array}{l}\text { The skills of the } \\
\text { employee }\end{array}$ & 0,621 & 0,360 & 0,992 \\
\hline 3 & $\begin{array}{l}\text { The facility of } \\
\text { the service }\end{array}$ & 0,863 & 0,360 & 0,962 \\
\hline 4 & $\begin{array}{l}\text { The employee } \\
\text { appeareance }\end{array}$ & 0,709 & 0,360 & 0,890 \\
\hline 5 & Socialization & 0,626 & 0,360 & 0,828 \\
\hline 6 & $\begin{array}{l}\text { The easiness of } \\
\text { pretender } \\
\text { electronic }\end{array}$ & 0,702 & 0,360 & 0,841 \\
\hline 7 & $\begin{array}{l}\text { The friendliness } \\
\text { user of the } \\
\text { pretender } \\
\text { electronic }\end{array}$ & $* * 0,198$ & 0,360 & 0,810 \\
\hline 8 & $\begin{array}{l}\text { Monitoring } \\
\text { pratender } \\
\text { elektronik }\end{array}$ & 0,357 & 0,360 & 0,699 \\
\hline 9 & $\begin{array}{l}\text { The } \\
\text { complettness of } \\
\text { pretender } \\
\text { electronic }\end{array}$ & 0,352 & 0,360 & 0,626 \\
\hline 10 & Punctuality & 0,756 & 0,360 & 0,831 \\
\hline 11 & Sincerity & 0,669 & 0,360 & 0,862 \\
\hline 12 & $\begin{array}{l}\text { Appropiate } \\
\text { service }\end{array}$ & 0,846 & 0,360 & 0,932 \\
\hline 13 & Tender speed & 0,873 & 0,360 & 0,905 \\
\hline 14 & $\begin{array}{l}\text { Free in losing } \\
\text { document }\end{array}$ & 0,838 & 0,360 & 0,932 \\
\hline 15 & $\begin{array}{ll}\begin{array}{l}\text { System } \\
\text { notification }\end{array} & \mathrm{n} \\
\end{array}$ & 0,812 & 0,360 & 0,903 \\
\hline 16 & $\begin{array}{l}\text { The stage of } \\
\text { process }\end{array}$ & 0,842 & 0,360 & 0,973 \\
\hline 17 & $\begin{array}{l}\text { Management } \\
\text { time in service }\end{array}$ & 0,861 & 0,360 & 0,818 \\
\hline 18 & $\begin{array}{l}\text { Willingness to } \\
\text { help }\end{array}$ & 0,789 & 0,360 & 0,944 \\
\hline 19 & Respond speed & 0,810 & 0,360 & 0,952 \\
\hline 20 & $\begin{array}{l}\text { The easiness in } \\
\text { getting } \\
\text { information }\end{array}$ & 0,723 & 0,360 & 0,888 \\
\hline 21 & $\begin{array}{l}\text { Work as job } \\
\text { desc }\end{array}$ & 0,921 & 0,360 & 0,981 \\
\hline 22 & Professionalism & 0,889 & 0,360 & 0,972 \\
\hline 23 & Punctuality & 0,921 & 0,360 & 0,982 \\
\hline 24 & $\begin{array}{l}\text { Technical } \\
\text { knowledge }\end{array}$ & 0,793 & 0,360 & 0,863 \\
\hline 25 & Polite behavior & 0,817 & 0,360 & 0,834 \\
\hline 26 & The care & 0,811 & 0,360 & 0,930 \\
\hline
\end{tabular}

\begin{tabular}{|c|l|l|l|l|}
\hline 27 & $\begin{array}{l}\text { Resonding to } \\
\text { complain }\end{array}$ & 0,865 & 0,360 & 0,914 \\
\hline 28 & $\begin{array}{l}\text { The priority of } \\
\text { the interest }\end{array}$ & 0,484 & 0,360 & 0,505 \\
\hline 29 & $\begin{array}{l}\text { Consultattion } \\
\text { service }\end{array}$ & 0,634 & 0,360 & 0,915 \\
\hline 30 & Personal Care & 0,807 & 0,360 & 0,915 \\
\hline
\end{tabular}

Note :

**Invalid

In internal assessments with as many as twenty respondents, the value of $\mathrm{n}$ was eighteen, so that the value of $r$ table was 0.378 . The results of the validity test of the internal assessment of the reality and expectation variables were shown in Table 2. Table 2 showed that the correlation in the reality variable of all item items was valid because the correlation value was greater than the r-table value of 0.378 , so the reliability test was carried out on it. For the expected variable, there were two items that were invalid because the correlation value was 0.077 and 0.326 , which were smaller than the r-table value of 0.378. The first invalid item was the tender implementation and the second was the system upgrade. It can be said that the system changed or upgraded because of the tender process to be delayed and it did not match the planned implementation schedule. Therefore, there were only two invalid questions. The question was omitted and there was no need for a reliability test on it.

Table 2. The Results of The Validity Test of Internal Assessments with Pearson Correlation

\begin{tabular}{|l|l|l|l|l|}
\hline No & \multicolumn{1}{|c|}{ Aspect } & $\begin{array}{c}\text { Reality } \\
\text { Corelation }\end{array}$ & $\begin{array}{c}\text { r } \\
\text { table } \\
\text { (sig } \\
\mathbf{5 \%} \\
\mathbf{N}=\mathbf{3 0}\end{array}$ & $\begin{array}{c}\text { Hope } \\
\text { Corelation }\end{array}$ \\
\hline 1 & $\begin{array}{l}\text { The appearance } \\
\text { of the employee }\end{array}$ & 0,870 & 0,378 & 0,899 \\
\hline 2 & $\begin{array}{l}\text { The integrity of the } \\
\text { employee }\end{array}$ & 0,813 & 0,378 & 0,960 \\
\hline 3 & $\begin{array}{l}\text { The facility of the } \\
\text { service }\end{array}$ & 0,651 & 0,378 & 0,935 \\
\hline 4 & $\begin{array}{l}\text { Structural } \\
\text { organization }\end{array}$ & 0,740 & 0,378 & 0,932 \\
\hline 5 & $\begin{array}{l}\text { Responsibility and } \\
\text { authority }\end{array}$ & 0,855 & 0,378 & 0,905 \\
\hline 6 & Socialization & 0,801 & 0,378 & 0,905 \\
\hline 7 & Accompaniment & 0,754 & 0,378 & 0,862 \\
\hline 8 & Tender plan & 0,726 & 0,378 & 0,982 \\
\hline 9 & Tender conducting & 0,444 & 0,378 & $* * 0,077$ \\
\hline 10 & Tender speed & 0,831 & 0,378 & 0,905 \\
\hline 11 & System upgrade & 0,675 & 0,378 & $* * 0,326$ \\
\hline 12 & Workload & 0,608 & 0,378 & 0,818 \\
\hline 13 & System notification & 0,850 & 0,378 & 0,847 \\
\hline 14 & $\begin{array}{l}\text { The sending of the } \\
\text { document }\end{array}$ & 0,862 & 0,378 & 0,829 \\
\hline 15 & $\begin{array}{l}\text { The stages of the } \\
\text { process }\end{array}$ & 0,963 & 0,378 & 0,935 \\
\hline 16 & $\begin{array}{l}\text { Koordinasi dengan } \\
\text { pihak terkait }\end{array}$ & 0,868 & 0,378 & 0,930 \\
\hline 17 & $\begin{array}{l}\text { Management time in } \\
\text { service }\end{array}$ & 0,879 & 0,378 & 0,973 \\
\hline 18 & Risk controling & 0,695 & 0,378 & 0,921 \\
\hline 19 & $\begin{array}{l}\text { The document in } \\
\text { problem solving }\end{array}$ & 0,760 & 0,378 & 0,879 \\
\hline 20 & Problem monitoring & 0,892 & 0,378 & 0,838 \\
\hline & & & \\
\hline
\end{tabular}




\begin{tabular}{|c|c|c|c|c|}
\hline 21 & $\begin{array}{l}\text { The number of the } \\
\text { employee }\end{array}$ & 0,639 & 0,378 & 0,719 \\
\hline 22 & $\begin{array}{l}\text { Work based on job } \\
\text { desc }\end{array}$ & 0,882 & 0,378 & 0,936 \\
\hline 23 & Professionalism & 0,801 & 0,378 & 0,910 \\
\hline 24 & Work hard & 0,789 & 0,378 & 0,900 \\
\hline 25 & $\begin{array}{l}\text { Technical } \\
\text { knowledge }\end{array}$ & 0,736 & 0,378 & 0,838 \\
\hline 26 & Team work & 0,815 & 0,378 & 0,936 \\
\hline 27 & $\begin{array}{ll}\text { Responding } & \text { to } \\
\text { complain } & \\
\end{array}$ & 0,649 & 0,378 & 0,858 \\
\hline 28 & $\begin{array}{l}\text { The priority of the } \\
\text { interest }\end{array}$ & 0,664 & 0,378 & 0,616 \\
\hline 29 & Consulation service & 0,833 & 0,378 & 0,809 \\
\hline 30 & Personal care & 0,774 & 0,378 & 0,870 \\
\hline
\end{tabular}

Note:

**In valid

\subsubsection{The result of reliability test}

After previously carrying out the validity test, the reliability test was carried out on the valid items so that the questionnaire used could be trusted as a tool for data collection.

In External Assessment, the results of the reliability test of the reality variable (E1) and the variable of expectations (E2), stated that all item questions were reliability as shown in Table 3 . From Table 3, it can be seen that the number of respondents $(\mathrm{N})$ analyzed in SPSS were twenty people. Because the respondent's answers were filled in all, none of them were blank. Then the valid number was $100 \%$. Cronbach's Alpha value was 0.973 for the reality variable and 0.987 for the hope variable. While $\mathrm{N}$ of Items (number of questions) were valid for the reality variable, there were 29 items and for the expectation variable. Besides, there are thirty questions. In addition, the Cronbach's Alpha value was 0.973 and $0.987>0.60$, as the basis for the decision making in the reliability test above, it can be concluded that all questions were reliable or consistent.

Table 3. External Assessment Reliability Test Results with Cronbach's Alpha Coefficient

\begin{tabular}{|c|c|c|c|}
\hline \multicolumn{4}{|c|}{ Reliability Test } \\
\hline $\begin{array}{l}\text { Cronbach's } \\
\text { Alpha } \\
\text { Coeficient }\end{array}$ & $\begin{array}{l}\text { Reality } \\
\text { Variable }\end{array}$ & $\begin{array}{l}\mathrm{R} \text { Table } \\
\text { (5\% Significancy) } \\
\mathrm{N}=30\end{array}$ & $\begin{array}{l}\text { Hope } \\
\text { Variable }\end{array}$ \\
\hline $\begin{array}{l}\text { Percentage } \\
\text { Validity in Case } \\
\text { Processing } \\
\text { Summary }\end{array}$ & $100 \%$ & - & $100 \%$ \\
\hline
\end{tabular}

In the Internal Assessment, the results of the reliability test of the reality variable (I1) and the variable of expectations (I2) stated that all item items were reliable as shown in Table 4.

From Table 4, it can be said that the number of respondents $(\mathrm{N})$ analyzed was twenty people with answers none of the respondents were empty, so the number of valid was $100 \%$. Thirty questions were valid for the reality variable and 28 items were valid for the expectation variable, with Cronbach's Alpha values of 0.957 and 0.988 . As the basis for decision making in the reliability test, namely, the Cronbach's Alpha value of the reality and expectation variables is 0.957 and $0.988>0.60$ and is greater than the r-table value of 0.387 , it can be concluded that all of these questions were reliable.

Table 4. Internal Assessment Reliability Test Results With Cronbach's Alpha Coefficient

\begin{tabular}{|l|l|l|l|}
\hline \multicolumn{4}{|c|}{ Reliability Test } \\
\hline $\begin{array}{l}\text { Cronbach's } \\
\text { Alpha } \\
\text { Coeficient }\end{array}$ & $\begin{array}{l}\text { Reality } \\
\text { Variable }\end{array}$ & $\begin{array}{l}\text { R Table } \\
\text { 5\% Significancy }) \\
\text { N=30 }\end{array}$ & $\begin{array}{l}\text { Hope } \\
\text { Variable }\end{array}$ \\
\hline $\begin{array}{l}\text { Percentage } \\
\text { Validity in Case } \\
\text { Processing } \\
\text { Summary }\end{array}$ & $100 \%$ & - & $100 \%$ \\
\hline $\begin{array}{l}\text { Cronbach's } \\
\text { Alpha }\end{array}$ & 0,957 & 0,387 & \\
\hline N of Items & 30 & - & 0,988 \\
\hline
\end{tabular}

\subsection{The Calculation of Index Satisfaction}

The calculation of the index satisfaction for each aspect was conducted to determine the aspects whichrequired an increase in service quality. The first step was to find a Likert score for each question by counting the number of respondents who answered according to a scale of 1 to 5 , then calculating the score for each question according to the Likert scale by multiplying the total number of respondents who chose the Likert score.

Next, we knew the total score for each question. Then, the index was calculated. The service quality go the average score index value for each dimension. In the calculation of the External Index, the results of the calculation of the external index were shown in Table 7 which explained that in the reality variable (E1), the tangible dimension of the completeness of the electronic pretender process had the lowest value, namely $70.76 \%$ while the highest was the aspect of employee appearance with $83,33 \%$. In the reliability dimension, the system notification aspect had the lowest score, $77.33 \%$, and the highest was the tender speed aspect of $84 \%$. In the Responsiveness dimension, the aspect of response speed got the lacking score. It was just in $77.33 \%$, and the aspect with the highest score was the ease of obtaining information and willingness to help, getting a score of $84 \%$. The fourth dimension, assurance, for punctuality was $78.67 \%$, while the highest was $82 \%$ for professionals. The last dimension, namely empathy, has the highest score of $84.67 \%$ in the caring aspect and the lowest $78.67 \%$ in the aspect of prioritizing the interests of the user. Of the five dimensions, the tangible dimension has the lowest index, namely $77.92 \%$.

In the expectation variable (E2), for the tangible dimension, the highest expectation was facilitated by electronic pre-tender. Besides, the value was $89.33 \%$. In 
the dimension of reliability, the highest score was obtained in the real aspect of serving, amounting to 90.67\%. Also, the Responsiveness dimension, the speed of response and the youngness of getting information was the highest expectation, namely $90 \%$. In the fourth dimension, namely assurance, the aspect of employee technical knowledge was the highest expectation, with a score of $92 \%$. The last dimension became the empathy, with the highest score in the aspect of care, namely $91.33 \%$. Of the five dimensions, the assurance dimension was the highest hope, amounting to $90.17 \%$.

Table 5. The Calculation of Internal Index

\begin{tabular}{|c|c|c|c|c|c|c|}
\hline \multirow{2}{*}{\multicolumn{2}{|c|}{ No Dimensi }} & \multirow{2}{*}{ Aspect } & \multicolumn{2}{|c|}{ Reality } & \multicolumn{2}{|c|}{ Hope } \\
\hline & & & Indeks & $S Q$ & Indeks & $S Q$ \\
\hline 1. & \multirow[b]{8}{*}{ 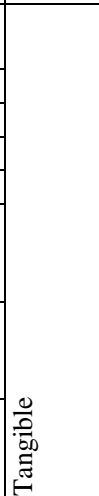 } & $\begin{array}{l}\text { The ability of the } \\
\text { employees }\end{array}$ & 80,67 & \multirow{8}{*}{77,92} & 88,67 & \multirow{8}{*}{87,25} \\
\hline 2. & & The skills of the employees & 80,67 & & 88,67 & \\
\hline 3. & & The facility of the service & 76,00 & & 86,00 & \\
\hline 4. & & The employee appeareance & 83,33 & & 88,67 & \\
\hline 5. & & Socialitation & 76,00 & & 86,00 & \\
\hline 6. & & $\begin{array}{l}\text { The easiness } \\
\text { with pre-rendered } \\
\text { electronic }\end{array}$ & 80,00 & & 89,33 & \\
\hline 8. & & $\begin{array}{l}\text { The monitoring of } \\
\text { pratender } \\
\text { electronic }\end{array}$ & 76,00 & & 86,00 & \\
\hline 9. & & $\begin{array}{l}\text { Completeness } \\
\text { the pre-rendering process } \\
\text { electronic }\end{array}$ & 70,67 & & 84,67 & \\
\hline 10. & \multirow{7}{*}{ : } & Keeping promises & 78,67 & \multirow{7}{*}{81,05} & 88,00 & \multirow{7}{*}{89,24} \\
\hline 11. & & Sincerity & 83,33 & & 90,67 & \\
\hline 12. & & The appropiate service & 80,00 & & 89,33 & \\
\hline 13. & & Tender speed & 84,00 & & 89,33 & \\
\hline 14. & & $\begin{array}{l}\text { Free from } \\
\text { losing } \\
\text { document }\end{array}$ & 83,33 & & 89,33 & \\
\hline 15. & & The notification of the system & 77,33 & & 88,00 & \\
\hline 16. & & The stage of the process & 80,67 & & 90,00 & \\
\hline 17. & \multirow{4}{*}{ 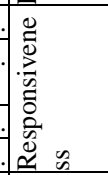 } & Service timing & 79,33 & \multirow{4}{*}{81,17} & 88,00 & \multirow{4}{*}{89,33} \\
\hline 18. & & $\begin{array}{l}\text { Willingness to } \\
\text { help }\end{array}$ & 84,00 & & 89,33 & \\
\hline 19. & & Respon speed & 77,33 & & 90,00 & \\
\hline 20. & & The easiness to get information & 84,00 & & 90,00 & \\
\hline 21. & \multirow{4}{*}{ 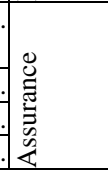 } & $\begin{array}{l}\text { The service based on } \\
\text { job description }\end{array}$ & 81,33 & \multirow{4}{*}{80,67} & 90,67 & \multirow{4}{*}{90,17} \\
\hline 22. & & Professionalism & 82,00 & & 90,00 & \\
\hline 23. & & Punctuality & 78,67 & & 88,00 & \\
\hline 24. & & Technical knowledge personnel & 80,67 & & 92,00 & \\
\hline 25. & \multirow{6}{*}{ 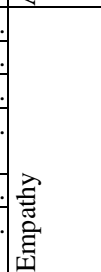 } & Polite behavior & 83,33 & \multirow{6}{*}{82,00} & 89,33 & \multirow{6}{*}{89,89} \\
\hline 26. & & The care & 84,67 & & 91,33 & \\
\hline 27. & & Responding complaint & 83,33 & & 90,67 & \\
\hline 28. & & $\begin{array}{l}\text { The priority } \\
\text { interests }\end{array}$ & 78,67 & & 89,33 & \\
\hline 29. & & The service of consultation & 82,00 & & 90,00 & \\
\hline 30. & & Personal Empathy & 80,00 & & 88,67 & \\
\hline
\end{tabular}

In the Calculation of the Internal Index (I), the results of the calculation of the internal index were shown in Table 8 . In the reality variable (I1), on the tangible dimension, the tender planning aspect received the lowest score, namely $65 \%$, while the highest was the aspect of mentoring, amounting to $86 \%$. Moreover, in reliability dimension, the system notification aspect has the lowest score, namely $71 \%$, and the tender speed has the highest value, namely $81 \%$. The value that was lacking in the responsiveness dimension was the document aspect of recording the problem, with a value of $65 \%$. Next, the highest aspect was the time of service delivery, with a value of $79 \%$. In the assurance dimension, the employees' technical knowledge received the lowest score, namely $66 \%$. In other hand, the maximum work aspect and cooperation with colleagues received the highest score, namely $77 \%$. The last dimension, emphaty, received the highest score in the aspect of consulting services, namely $79 \%$, and the lowest, at $64 \%$, was on the aspect of prioritizing the interests of users. Of the five dimensions, the responsiveness dimension has the lowest index value, namely $70 \%$.

For the expectation variable (I2), employee integrity was the highest expectation on the tangible dimension, with a value reaching $90 \%$. Meanwhile, dimension of reliability, the highest score was in the aspect of coordination with related parties, with a score of $87 \%$. The highest expectation on the responsiveness dimension was service delivery time, with a value of $87 \%$. For the assurance dimension, working optimally was the highest hope, with a score of $88 \%$. Meanwhile, on the empathy dimension, the highest score was obtained by the aspect of consulting services, with a value of $84 \%$. Finally, the tangible dimension is the highest expectation, with a value of $86.88 \%$.

Table 6. The Calculation of Internal Index

\begin{tabular}{|c|c|c|c|c|c|c|}
\hline \multirow[t]{2}{*}{ No } & \multirow{2}{*}{ Dimension } & \multirow{2}{*}{ Aspect } & \multicolumn{2}{|c|}{ Reality } & \multicolumn{2}{|c|}{ Hope } \\
\hline & & & Indeks & SQ & Indeks & SQ \\
\hline 1. & \multirow{8}{*}{ 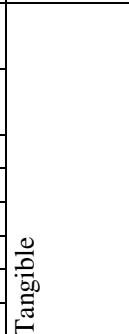 } & $\begin{array}{l}\text { The personal branding of the } \\
\text { employee }\end{array}$ & 81 & \multirow{8}{*}{75,38} & 87 & \multirow{8}{*}{86,88} \\
\hline 2. & & $\begin{array}{l}\text { The intergrity of the } \\
\text { employmee }\end{array}$ & 77 & & 90 & \\
\hline 3. & & The facility of the service & 76 & & 89 & \\
\hline 4. & & Structural organization & 73 & & 86 & \\
\hline 5. & & Responsibilty and Authority & 75 & & 85 & \\
\hline 6. & & Socialization & 70 & & 85 & \\
\hline 7. & & Accompaniment & 86 & & 88 & \\
\hline 8. & & Tender plan & 65 & & 85 & \\
\hline 10. & \multirow[b]{6}{*}{ : } & Tender speed & 81 & \multirow{6}{*}{77,50} & 85 & \multirow{6}{*}{84,83} \\
\hline 12. & & Workload & 77 & & 86 & \\
\hline 13. & & The notification of the system & 71 & & 81 & \\
\hline 14. & & \begin{tabular}{|l} 
Delivery \\
document
\end{tabular} & 79 & & 84 & \\
\hline \multirow{2}{*}{\begin{tabular}{|l|}
15. \\
16. \\
\end{tabular}} & & The stages & 78 & & 86 & \\
\hline & & $\begin{array}{l}\text { Coordination } \\
\text { With related parties }\end{array}$ & 79 & & 87 & \\
\hline 17. & \multirow{5}{*}{ 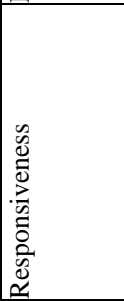 } & Management time in service & 79 & \multirow{5}{*}{70,00} & 87 & \multirow{5}{*}{82,80} \\
\hline 18. & & \begin{tabular}{|l|} 
Control \\
risk
\end{tabular} & 69 & & 84 & \\
\hline 19. & & $\begin{array}{l}\text { The document in } \\
\text { recording } \\
\text { problem }\end{array}$ & 65 & & 83 & \\
\hline 20. & & $\begin{array}{l}\text { Monitoring } \\
\text { problem }\end{array}$ & 67 & & 85 & \\
\hline 21. & & Number of employees & 70 & & 75 & \\
\hline 22. & \multirow{4}{*}{ 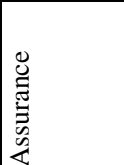 } & Work as job description & 74 & \multirow{4}{*}{73,40} & 86 & \multirow{4}{*}{85,20} \\
\hline 23. & & Professionalism & 73 & & 83 & \\
\hline 24. & & Work hard & 77 & & 88 & \\
\hline 25. & & $\begin{array}{l}\text { Technical } \\
\text { personnel }\end{array}$ & 66 & & 82 & \\
\hline
\end{tabular}




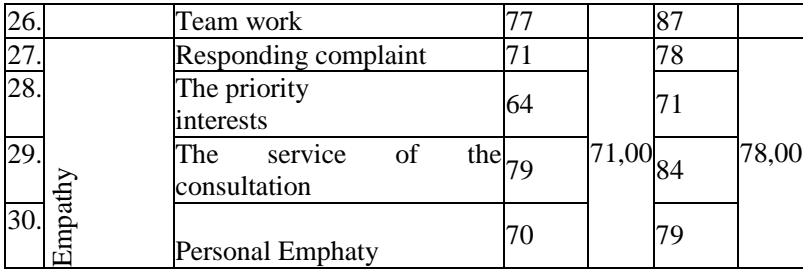

\section{CONCLUSIONS}

From the results of the external assessment, the level of satisfaction of procurement services based on reality, the highest value came from the empathy dimension of the caring aspect, while the lowest value was the tangible dimension of the completeness aspect of the electronic pre-tender process. Meanwhile, services that are most expected to be in the dimension of assurance, the employees of the procurement of goods or services are expected to have good technical knowledge so that they can quickly solve technical problems. If we look at each dimension, it turns out that assurance has the largest gap. Therefore, all aspects of the assurance dimension are the priority for improvement so that the gap can be minimized, while the smallest gap occurs in the empathy dimension. By doing so, the services provided are almost close to user expectations.

Implications: Entrepreneurial activity that falls into the "fairly decent" category would have an effect on the long-term viability of the company if not changed. Personality, relationship skills, marketing skills, organizational skills, and financial management skills must all be strengthened. If the competitiveness of companies in the high enough group does not increase, it will have a negative effect on their long-term profitability. Product and marketing innovation, as well as product and marketing innovation, must be strengthened. Entrepreneurial activity that is still very good would have an effect on the competitiveness of the business. As a result, if a company owner wishes to make a lot of money. According to research, entrepreneurs have a high level of competition, so they must boost or strengthen their entrepreneurial actions.

\section{ACKNOWLEDGMENTS}

I would like to express my gratitude to Universitas Pendidikan Indonesia especially the Conference Chair, Technical Chairperson, Scientific Committee team and all GCBME members who have facilitated my research results into the publication of scientific papers at the Global Conference on Business, Management and Entrepreneurship.

\section{REFERENCES}

[1] Pengadaan Barang/Jasa Pemerintah, Peraturan Presiden Republik Indonesia No. 54, 2010.
[2] Layanan Pengadaan Secara Elektronik (LPSE), Peraturan Kepala LKPP No. 2, 2010.

[3] e-Tendering, Peraturan Kepala LKPP No. 1, 2011.

[4] Standar Dokumen Pengadaan Barang/Jasa Pemerintah secara Elektronik, Peraturan Kepala LKPP No. 5, 2011.

[5] Informasi dan Transaksi Elektronik, UndangUndang No. 11, 2008.

[6] M.R. Islam, "Application of SERVQUAL Model in Customer Service of Mobile Operator: A Study from the Context of Bangladesh,"European Journal or Business and Management, Vol. 4, No. 1, hal. $47-$ $54,2012$.

[7] V.L. Purcarea, I.R. Gheorghe, dan C.M. Petrescu, "The Assessment of Perceived Service Quality of Public Health Care Services in Romania using the SERVQUAL Scale," Procedia Economics and Finance, Vol. 6, hal. 573-585, 2013.

[8] Lindgren dan G. Jansson "Electronic Services in the Public Sector: A Conceptual Framework," Government Information Quarterly, Vol. 30, No. 2, hal.163-172. 2013.

[9] Rahman, M. Hasan, M.A. Mia, "Mobile Banking Service Quality and Customer Satisfaction in Bangladesh: An Analysis," The Cost and Management, Vol. 45, No. 2, hal. 25-32, 2017.

[10] Parasuraman, V.A. Zeithaml, dan L.L. Berry, "SERVQUAL: A Multiple-Item Scale for Measuring Consumer Perceptions of Service Quality," Journal of Retailing, Vol. 64, No. 1, hal. 12-40, 1988.

[11] Saidani dan S. Arifin, "Pengaruh Kualitas Produk dan Kualitas Layanan Terhadap Kepuasan Konsumen dan Minat Beli pada Ranch Market," Jurnal Riset Manajemen Sains Indonesia, Vol. 3, No. 1, hal. 1-22, 2012.

[12] Hidayat, (2012) "Uji Pearson Product Moment dan Asumsi Klasik," [Online], https://www.statistikian.com/2012/07/pearson-danasumsi-klasik.html, tanggal akses: 26-Mar-2019.

[13]V.W. Sujarweni, "SPSS untuk Penelitian," Yogyakarta, Indonesia: Pustaka Baru Press, 2014.

[14]Ayo Nambah Ilmu, (2016) "Validitas dan Reliabilitas Instrumen Penelitian - Pengertian dan Jenis-jenis," [Online], http://ayo-nambah-ilmu. blogspot.com/2016/06/validitas-dan-reliabilitasinstrumen.html, tanggal akses: 28-Mar-2019.

[15]B.S. Iskandar dan S. Sugiharto, "Analisa Pengaruh Faktor-faktor Service Quality Terhadap Customer Satisfaction di Restoran Mr. Pancake Surabaya," Jurnal Manajemen Pemasaran, Vol. 1, No. 1, hal. 1-12, 2013 